\title{
What Drives Consumption Booms?
}

\author{
Peter J. Montiel
}

\begin{abstract}
Consumption booms have been common in both industrial and developing countries, and several explanations have been offered for their occurrence. These include economywide wealth effects associated with favorable movements in the terms of trade or euphoric expectations triggered by macroeconomic reforms, Ricardian effects associated with fiscal stabilization, lending booms following financial liberalization, and a variety of distortions in intertemporal relative prices. Using a large cross-country sample of booms, this article assesses how widely applicable these explanations are. The key finding is that wealth effects linked to favorable movements in the terms of trade and anticipated improvements in macroeconomic performance seem to have been more important empirically than explanations relying primarily on fiscal phenomena or distortions in intertemporal relative prices.
\end{abstract}

Consumption booms, common in both industrial and developing countries, have been associated with a variety of macroeconomic events, including stabilization of high inflation, surges in capital inflows, the implementation of marketoriented structural reforms (especially trade and financial liberalization), and favorable movements in the external terms of trade. They are often perceived as policy problems because of their effects on demand for home goods, the trade balance, and the resources available for investment. The emergence of a consumption boom may, for example, undermine the objective of stabilizing inflation by putting upward pressure on the prices of home goods. Similarly, a consumption boom that arises during an episode of capital inflows may significantly increase the country's current account deficit, which may, in turn, undermine the credibility of the prevailing exchange rate and contribute to capital flow reversals. The recent example of Mexico has now become notorious, but similar, if relatively muted, booms have characterized several other capital-importing countries in Latin America.

Despite the occasional attention given to specific episodes, researchers have only recently begun to study the causes of consumption booms in a systematic way. By and large, their analysis has been confined to speculation based on casual empiricism in descriptive studies focusing on other issues (such as stabilization episodes and surges in capital inflows). ${ }^{1}$ In these contexts several competing

1. Exceptions include Rebelo and Vegh (1996) and Reinhart and Vegh (1995).

Peter J. Montiel is professor in the Department of Economics at Williams College. His e-mail address is pmontiel williams.edu. The author gratefully acknowledges comments on earlier drafts from Barry Bosworth, Carlos Vegh, and two anonymous referees.

O 2000 The International Bank for Reconstruction and Development / THE WORLD BANK 
hypotheses have been offered to explain the emergence of booms, attributing the phenomenon to changes in various determinants of aggregate consumption expenditures.

Because consumption booms have so often been perceived as posing challenges for macroeconomic policy, and because they have been attributed to a variety of different factors, it is useful to examine whether the data reveal systematic patterns in their emergence. The objective of this article is to establish a set of stylized facts concerning the macroeconomic environments in which consumption booms have arisen.

Based on a large sample of consumption booms, identified according to a set of objective criteria, I use two approaches to determine the circumstances surrounding their emergence. First, for a restricted sample of countries (dictated by the available data), I estimate a probit regression to explain the emergence of booms as a function of the explanatory variables typically emphasized in the literature. This exercise identifies the conditions that favor the emergence of booms in general, without necessarily explaining the emergence of any particular episode.

Second, I take up the question of whether consumption booms are all alike by determining the extent to which the behavior of certain key macroeconomic variables during each episode was consistent with the hypotheses that have been offered to explain booms. I take the hypotheses one at a time. This narrows the scope of potential explanations for each episode, without attempting the more ambitious task of measuring the contributions made by each of the remaining hypotheses.

\section{IDENTIFYING CONSUMPTION BOOMS}

What exactly do we mean by a consumption boom? Based on considerations discussed in Montiel (1998), in this article I identify a consumption boom as an unusual increase in the ratio of real private consumption expenditures to real national income. Intuitively, a boom should be characterized by a large and sustained deviation in the ratio of consumption to gross domestic product (GDP) from its "normal" value that is driven by the behavior of consumption, rather than that of income. I construct the sample of consumption booms used here by applying an operational version of this criterion to the data from a large sample of industrial and developing countries. The sample includes all countries in the World Bank's World Saving Database that have at least 20 annual observations on both real private consumption and real GDP for the period 1960-95. There are 91 such countries, of which 23 are industrial countries and 68 are developing countries (the sample includes no transition economies).

To make the intuitive characterization of booms operational, I use the following procedure to identify consumption booms in the sample. First, for each country I test the ratio of real private consumption to real GDP for trend stationarity. I detrend (if necessary) series that prove to be trend stationary to identify and 
separate out secular movements. Series that appear to be nonstationary are examined further for trend breaks and structural shifts that may account for the rejection of stationarity. I introduce shift parameters or trend breaks where appropriate to render the series stationary. Second, I calculate transitory components of each series as deviations of the original series from the deterministic trend component.

A boom is said to occur during a period characterized by a "run" of positive deviations of the ratio of private consumption to GDP from its deterministic trend. To minimize the incidence of spurious booms generated by errors in the data, particularly among the large number of low-income countries in the sample, identified booms have to meet three additional conditions: the run must contain at least one observation greater in magnitude than two standard deviations of the transitory consumption-ratio series, the run must consist of at least two consecutive annual observations, and the run must contain at least two consecutive observations for which the rate of growth of real private consumption exceeds its sample mean. ${ }^{2}$

The resulting sample of consumption booms among the 91 sample countries totaled 40 during 1960-95 (table 1). Thirty-five countries experienced at least one boom episode, and 5 of these experienced more than one episode during the period. The sample of consumption booms contains episodes in both industrial ( 9 episodes) and developing ( 31 episodes) countries, and in all geographic regions. Booms are also widely dispersed across time. Eight booms originated in the 1960s, 19 in the 1970s, 12 in the 1980s, and 1 in the 1990s.

The frequency of booms in the sample suggests that they can arise under diverse circumstances. The fact that consumption booms are fairly common makes it highly unlikely that they arise only as the result of exceptional policy environments. Nonetheless, this conjecture can be tested only by examining the circumstances surrounding their emergence.

\section{What Causes Consumption BoOMs?}

In principle, a consumption boom may be driven by a variety of macroeconomic factors. There is no reason to believe that booms share one cause or a set of causes. Nonetheless, it is useful to determine whether booms have arisen more readily in some circumstances than in others-that is, whether any particular set of macroeconomic circumstances has systematically influenced the probability that a boom will emerge. This section reports estimates of a set of probit regres-

2. Private consumption data are often estimated as residuals from categories that are themselves indirectly estimared. The compounding of measurement errors in this procedure introduces a substantial amount of noise to the time series for private consumption, a problem that may be particularly severe for small low-income countries. This problem could introduce spurious "boom" observations and generate selectivity bias by overrepresenting poor countries (with presurnably worse data) in the boom sample. I have tried to reduce the severity of this problem by relying only on the "cleaned up" consumption and GDP data from the World Saving Database as well as by using a restrictive set of criteria in identifying booms. 
Table 1. Consumption Booms

\begin{tabular}{|c|c|c|c|}
\hline Country & Data & Stationarity & Booms \\
\hline \multicolumn{4}{|l|}{ Industrial countries } \\
\hline Australia & $1960-94$ & $S$ & None \\
\hline Austria & $1960-94$ & $\mathrm{D}$ & None \\
\hline Belgium & $1960-94$ & $S$ & None \\
\hline Canada & $1960-94$ & $\mathrm{~s}$ & $1960-63$ \\
\hline Denmark & $1960-94$ & TS & $1975-79$ \\
\hline Finland & $1960-94$ & $S$ & None \\
\hline France & $1960-94$ & D & None \\
\hline Germany & $1960-94$ & T2S & None \\
\hline Greece & $1960-94$ & $\mathrm{~T} 2 \mathrm{~S}$ & None \\
\hline \multirow[t]{2}{*}{ Iceland } & $1960-94$ & $\mathrm{~T} 2 \mathrm{~S}$ & $1970-74$ \\
\hline & & & $1987-88$ \\
\hline Ireland & $1960-94$ & TS & $1978-81$ \\
\hline Italy & $1960-94$ & TS & None \\
\hline Japan & $1960-94$ & $\mathrm{~S}$ & None \\
\hline Luxembourg & $1960-94$ & $\mathrm{~T} 2 \mathrm{~S}$ & None \\
\hline Netherlands & $1960-94$ & $\mathbf{S}$ & $1975-83$ \\
\hline New Zealand & $1960-94$ & $D, T$ & $1972-75$ \\
\hline Norway & $1960-94$ & TS & $1975-77$ \\
\hline Portugal & $1960-94$ & $\mathbf{S}$ & $1971-78$ \\
\hline Spain & $1960-94$ & D & None \\
\hline Sweden & $1960-94$ & TS & None \\
\hline Switzerland & $1960-94$ & $\mathrm{~T} 2 \mathrm{~S}$ & None \\
\hline United Kingdom & $1960-94$ & $\mathrm{D}$ & None \\
\hline United States & $1960-94$ & $\mathrm{~T} 2 \mathrm{~S}$ & None \\
\hline \multicolumn{4}{|l|}{ Developing conntries } \\
\hline Algeria & $1960-94$ & D & None \\
\hline Bangladesh & $1960-94$ & D & $1983 \div 89$ \\
\hline Benin & $1960-94$ & $\mathrm{D}$ & None \\
\hline Bolivia & $1960-94$ & $\mathrm{D}$ & None \\
\hline Botswana & $1975-94$ & $\mathrm{D}$ & None \\
\hline Brazil & $1960-94$ & TS & None \\
\hline Burkina Faso & $1965-94$ & $\mathrm{~T} 2 \mathrm{~S}$ & None \\
\hline \multirow[t]{2}{*}{ Burundi } & $1960-94$ & $\mathrm{~T} 2 \mathrm{~S}$ & $1961-63$ \\
\hline & & & $1979-82$ \\
\hline Cape Verde & $1973-93$ & TS & $1976-80$ \\
\hline Central African Republic & $1960-94$ & TS & None \\
\hline Chile & $1960-94$ & TS & $1978-81$ \\
\hline China & $1960-94$ & D & None \\
\hline Colombia & $1960-94$ & D & None \\
\hline Congo & $1960-94$ & D & None \\
\hline Costa Rica & $1960-94$ & $\mathrm{~T} 2 \mathrm{~S}$ & $1964-71$ \\
\hline \multirow[t]{2}{*}{ Côte d'Ivoire } & $1965-94$ & $\mathrm{D}$ & $1969-70$ \\
\hline & & & $1976-77$ \\
\hline Cyprus & $1975-94$ & $\mathbf{S}$ & 1991-92 \\
\hline Dominican Republic & $1960-94$ & T2S & None \\
\hline Ecuador & $1965-94$ & $\mathrm{D}$ & None \\
\hline Egypt, Arab Rep. & $1974-94$ & TS & None \\
\hline Gabon & $1960-93$ & $\mathbf{S}$ & None \\
\hline Gambia, The & $1960-94$ & D & $1984-85$ \\
\hline
\end{tabular}




\begin{tabular}{|c|c|c|c|}
\hline Country & Data & Stationarity & Booms \\
\hline Ghana & $1960-94$ & $S$ & None \\
\hline Guinea-Bissau & $1970-94$ & D & $1971-75$ \\
\hline Guyana & $1960-88$ & TS & None \\
\hline Honduras & $1960-94$ & $\mathrm{D}$ & $1976-77$ \\
\hline Hong Kong & $1965-94$ & TS & None \\
\hline India & $1960-94$ & TS & None \\
\hline Indonesia & $1960-94$ & $\mathbf{S}$ & $1981-87$ \\
\hline Iran & $1974-94$ & TS & None \\
\hline Israel & $1960-94$ & T2S & None \\
\hline Jamiaica & $1960-93$ & $\mathrm{~T} 2 \mathrm{~S}$ & $1987-90$ \\
\hline Kenya & $1960-94$ & T2S & None \\
\hline Korea, Rep. of & $1960-94$ & T2S & None \\
\hline Lesotho & $1960-94$ & T2S & $1975-77$ \\
\hline Madagascar & $1960-94$ & $\mathbf{S}$ & None \\
\hline Malawi & $1960-94$ & T2S & None \\
\hline Malaysia & $1960-94$ & $\mathrm{~T} 2 \mathrm{~S}$ & $1978-85$ \\
\hline Mali & $1967-94$ & T2S & $1983-85$ \\
\hline \multirow[t]{2}{*}{ Mauritania } & $1960-94$ & TS & $1973-77$ \\
\hline & & & $1982-84$ \\
\hline Mexico & $1960-94$ & $\mathrm{D}, \mathrm{T}$ & $1989-94$ \\
\hline Morocco & $1960-94$ & T2S & None \\
\hline Nicaragua & $1960-94$ & D & None \\
\hline Niger & $1960-94$ & D & None \\
\hline Nigeria & $1960-94$ & D & $1978-86$ \\
\hline Pakistan & $1960-94$ & T2S & None \\
\hline Panama & $1960-94$ & T2S & None \\
\hline Papua New Guinea & $1961-94$ & $\mathrm{~T} 2 \mathrm{~S}$ & None \\
\hline Paraguay & $1960-94$ & $\mathbf{S}$ & $1962-69$ \\
\hline Peru & $1960-94$ & $\mathbf{S}$ & None \\
\hline Philippines & $1960-94$ & D & None \\
\hline Rwanda & $1960-94$ & $S(1960-90)$ & None \\
\hline Senegal & $1960-94$ & $\mathbf{S}$ & None \\
\hline Singapore & $1960-94$ & $S$ & None \\
\hline South Africa & $1960-94$ & TS & None \\
\hline Sri Lanka & $1960-94$ & $\mathrm{D}, \mathrm{T}$ & $1980-83$ \\
\hline Sudan & $1960-91$ & T2S & $1977-85$ \\
\hline Taiwan (China) & $1965-94$ & T2S & None \\
\hline Thailend & $1960-94$ & TS & None \\
\hline Togo & $1960-94$ & T2S & $1966-70$ \\
\hline Trinidad and Tobago & $1960-94$ & TS & $1982-84$ \\
\hline Tunisia & $1961-94$ & D & None \\
\hline Turkey & $1960-94$ & $\mathrm{D}, \mathrm{T}$ & $1982-86$ \\
\hline Uruguay & $1960-94$ & $T 2 S$ & $1969-75$ \\
\hline Venezuela & $1974-94$ & T2S & None \\
\hline Zaire & $1970-89$ & $\mathbf{S}$ & None \\
\hline Zambia & $1960-94$ & $S$ & $1966-70$ \\
\hline & & & $1987-90$ \\
\hline Zimbabwe & $1965-93$ & $S$ & $1978-83$ \\
\hline
\end{tabular}

Note: $S$ = stationary, $D$ a stationary after introduction of a dummy, $T S$ a trend stationary, $T 2 S$. stationary after removal of quadratic trend.

Source: Author's calculations based on information in the World Bank's World Saving Database. 
sions that seek to explain the probability of booms as a function of macroeconomic variables derived from existing hypotheses of their origins. ${ }^{3}$

\section{Specification}

The first step in the analysis is to express each hypothesis in terms of links between observable macroeconomic variables. I take them up one at a time.

INCOME REDISTRIBUTION. Consumption booms may arise as the result of a significant redistribution of income in favor of lower-income groups, itself the outcome of populist policies. Since lower-income groups are more likely to be liquidityconstrained than higher-income groups, such a redistribution would tend to shift income from unconstrained to constrained households, thereby causing aggregate consumption to rise. The question, then, is whether the booms identified above were indeed associated with large redistributions of income in favor of lower-income households.

Unfortunately, to answer this question, we would need annual data on household income distribution for large groups of countries. The most comprehensive data set of this type is the Deininger and Squire (1996) database. But even these data barely provide enough information to draw tentative inferences about what may have been happening to the distribution of household income for a subset of the consumption booms in the sample. Ideally, we want data on the distribution of household income for a number of years immediately before, during, and after the boom in order to assess whether the boom was associated with a systematic change in that distribution. But the best we can do in most cases is to derive the Gini coefficient or the household distribution of income by quintile for one or more noncontiguous years shortly before, during, and after the boom. For this reason I exclude the income-distribution hypothesis from the probit estimation.

CHANGES IN INTERTEMPORAL RELATIVE PRICES. A second category of explanations for the emergence of booms focuses on changes in intertemporal relative prices. These hypotheses come in several forms. The first operates in the context of exchange rate-based stabilization with inflation inertia. Rodríguez (1982) argues that in economies that are financially open, domestic nominal interest rates would tend to fall when the exchange rate is used as a nominal anchor to stabilize inflation. If expectations of inflation remain high, however (say, because of inflation inertia), the domestic real interest rate would tend to fall. And if consumption responds to the real interest rate, this fall would trigger an increase in consumption spending. The empirical question, then, is whether booms are associated with a contemporaneous reduction in real interest rates.

The second mechanism involves "incredible" exchange rate-based stabilization. Dornbusch (1985) suggests that exchange rate-based stabilizations that are not expected to last tend to create an intertemporal distortion in the form of an

3. The approach here is analogous to that which has recently been employed to study the determinants of currency crises. See, for example, Eichengreen, Rose, and Wyplozz (1995). 
expected future increase in the real price of importables (a real exchange rate depreciation). To the extent that consumption durables fall into this category, the anticipation that their price will rise in the future will drive consumers to shift the purchase of durables to the present. The implication is that such stabilizations, if they are not expected to be sustainable, may be associated with private consumption booms driven by temporary real exchange rate appreciation.

But even if the real exchange rate is not expected to change, intertemporal relative prices may change so as to favor increased consumption in the present. The mechanism involves a cash-in-advance technology for making transactions. If money reduces the cost of economic transactions, lower nominal interest rates will lower the opportunity cost of holding the money balances required to effect current transactions, and thus current consumption will be cheap relative to future consumption. Assuming sufficient intertemporal substitutability in consumption, households will shift consumption to the present. Thus to assess the potential role of this mechanism-due to Calvo (1989) and dubbed the "temporariness" hypothesis-we must determine whether booms are associated with nominal interest rates that are temporarily lower.

Each of these hypotheses focuses on a specific macroeconomic variable: the real interest rate, the real exchange rate, or the nominal interest rate. Each implies a specific path for the relevant variable before, during, and after the boom in order to account for the boom's inception and end: the Rodriguez hypothesis suggests that the real interest rate should fall during the boom and rise subsequently; the Dornbusch hypothesis implies that the real exchange rate should appreciate during the boom and be expected to depreciate subsequently; and the Calvo hypothesis holds that the nominal exchange rate should fall during the boom and be expected to rise subsequently.

In the probit regression I attempt to capture these transitory movements by measuring each variable in the form of deviations from the country-specific sample mean. According to the three hypotheses, then, the probability that a particular observation will be associated with a consumption boom will be higher if the real and nominal interest rates are below their sample means and if the real exchange rate is above its sample mean. ${ }^{4}$

WEALTH EFFECTS. A boom may arise because the private sector perceives an increase in its wealth and adjusts its consumption path accordingly. Private wealth may increase with an increase in national wealth, which is shared by the private and public sectors, arising from a perceived permanent improvement in the country's terms of trade or a change in the policy regime that is expected to accelerate economic growth. Alternatively, private wealth may increase because

4. I take data on nominal interest rates from the World Saving Database, using market-determined rates (money market rates or T-bill rates) whenever possible and deposit rates otherwise. 1 compute the real interest rate as an exact ex post real interest rate based on the consumer price index. The real exchange rate data are the trade-weighted real effective exchange rate series computed by the International Monetary Fund, which defines an appreciation as an increase in the real effective exchange rate. 
of a change in fiscal policy that is perceived to reduce the present value of the private sector's future tax liabilities.

To evaluate the potential role of these variables, the probit regression examines whether the booms in the sample were associated with contemporaneous improvements in the country's terms of trade, increases in the rate of economic growth, and reductions in the ratio of real public consumption to GDP.

CREDT EXPANSION. Finally, consumption booms also have been attributed to a rapid expansion of credit to the private sector. The expansion may arise from a variety of sources, involving the relaxation of credit constraints triggered by explicit or implicit backing of financial liabilities by the public sector. Two versions are common.

First, booms have been said to result from the relaxation of credit constraints at the level of the household or firm following inappropriate domestic financial liberalization. Specifically, the rapid liberalization of a previously repressed financial system without appropriate regulatory and supervisory mechanisms for financial institutions, but with explicit or implicit deposit insurance and poor capitalization of banks, creates a structure of incentives for bank managers that fosters excessive risk taking in their portfolio decisions. This risky lending may take the form of an excessive expansion of consumption loans or loans used to acquire (or secure) stocks or real estate. Lending booms for the latter may, in turn, trigger asset price bubbles in real estate or in the stock market. Whether consumption loans expand disproportionately (thus alleviating liquidity constraints on households) or asset price bubbles arise (thus exerting wealth effects on household spending), a boom in private consumption may be the result.

In the second version of this credit story, the credit expansion originates abroad, and liquidity constraints are no longer binding for the country as a whole. Just as in the case of a domestically driven credit expansion, a large capital inflow that is at least partially intermediated by the domestic financial system can set off the rapid expansion of domestic credit and the development of asset price bubbles.

What these phenomena have in common is that the resulting consumption boom is associated with a rapid expansion of credit to the private sector from domestic financial intermediaries. This expansion may itself be the source of the boom, or it may in part reflect growth in the demand for credit triggered by the wealth effects associated with asset price bubbles. In either case, a rapid increase in the rate of expansion of credit to the private sector will be a symptom of such finance-driven booms. Accordingly, the final variable to be included in the probit regression is the ratio of the flow of credit to the private sector to GDP. If the credit expansion view is correct, an increase in this variable should be associated with a higher probability of observing a boom in progress.

\section{Probit Results}

The data set I use in this article consists of annual observations of the variables listed above for 91 countries during the period 1960-95-a total of 3,276 poten- 
tial panel observations. However, complete data for all of the variables (except for the income distribution variable) were available for only 640 observations, including 40 boom observations. I thus base the probit estimates on this reduced sample, consisting of an unbalanced panel of 51 countries.

To cope with potential endogeneity problems, I estimate four different probit regressions. Equation 1 includes the contemporaneous values of all the variables in the form suggested by the hypotheses described above. One problem with estimating the regression in this form, however, is that many of the explanatory variables are likely to respond endogenously to the emergence of a boom. This obviously hampers our ability to draw inferences about the causal roles that the explanatory variables may have played.

As a simple procedure to reduce the potential effects of feedback from booms to the explanatory variables, equation 2 replaces all of the potentially endogenous variables with their lagged values. ${ }^{5}$ However, this procedure may bias the results against hypotheses that rely on the response of consumption expenditures to contemporaneous changes in domestic interest rates. Accordingly, equation 3 adopts the alternative approach of instrumenting for the two domestic interest rate variables, using as instruments the contemporaneous U.S. nominal and real interest rates. It also includes the lagged values of the other endogenous variables and the two exogenous variables. I run two variants of this regression, with and without the real interest rate (equations $3 a$ and $3 b$ ).

Overall, the estimates suggest that changes in domestic interest rates have not played an important role in generating the booms observed in this sample (table 2). The coefficients of the nominal and real interest rate variables do not approach statistical significance with the theoretically predicted (negative) signs in any of the regressions. Similarly, the results provide little support for the credit hypothesis or for the hypothesis of a wealth mechanism operating through higher growth of real GDP. With the exception of equation 1 , in which endogeneity is a strong suspect, the coefficients of the credit and growth variables have negative signs, the opposite of what would be predicted by the "lending boom" or "growth euphoria" hypotheses.

Booms in this sample instead tend to be associated with appreciated real exchange rates and favorable terms of trade. The coefficients on both of these variables are statistically significant and have theoretically appropriate signs in equations 1 and 2 , and the terms of trade variable continues to perform well in equation 3a. Although the $p$-value of the lagged real exchange rate rises somewhat (to 0.19 ) in equation $3 \mathrm{a}$, the sign of this variable proves to be robust across equations. The loss of statistical precision in the estimate of its coefficient in equation 3a may be due to covariation with the instrumented value of the real interest rate. Indeed, the correlation between the lagged real exchange rate and the real interest rate rises from 0.13 in equation 2 to 0.43 in equation 3a. Dropping the

5. I assume that the terms of trade and ratio of public consumption to GDP are exogenous in this exercise. The latter is obviously problematic, but the exogeneity of public consumption within a particular year seems warranted by well-known problems of fiseal rigidity. 
Table 2. Determinants of Consumption Booms: Probit Results

\begin{tabular}{lcccc}
\hline & \multicolumn{4}{c}{ Equation } \\
\cline { 2 - 5 } Variable & $(1)$ & $(2)^{*}$ & $(3 a)^{b}$ & $(3 b)^{c}$ \\
\hline Constant & -1.702 & -1.626 & -1.580 & -1.634 \\
& $(0.12)$ & $(0.109)$ & $(0.142)$ & $(0.113)$ \\
Real exchange rate & $0.007^{*}$ & $0.002^{*}$ & 0.001 & $0.002^{*}$ \\
& $(0.003)$ & $(0.001)$ & $(0.001)$ & $(0.001)$ \\
Real interest rate & 0.016 & 0.003 & -0.037 & \\
& $(0.009)$ & $(0.007)$ & $(0.059)$ & \\
Nominal interest rate & -0.002 & 0.000 & 0.005 & 0.006 \\
& $(0.004)$ & $(0.000)$ & $(0.023)$ & $(0.023)$ \\
Real GDP growth & 0.030 & -0.019 & -0.022 & -0.017 \\
& $(0.022)$ & $(0.019)$ & $(0.021)$ & $(0.019)$ \\
Terms of trade & $1.470^{* *}$ & $2.024^{* *}$ & $1.995^{* *}$ & $2.021^{* *}$ \\
& $(0.352)$ & $(0.316)$ & $(0.317)$ & $(0.315)$ \\
Government consumption & 1.063 & -3.016 & -3.041 & -3.179 \\
& $(3.286)$ & $(4.012)$ & $(3.971)$ & $(3.922)$ \\
Credit to the private sector & 1.063 & -2.311 & -2.182 & -2.232 \\
& $(3.286)$ & $(1.194)$ & $(1.173)$ & $(1.178)$ \\
Likelihood ratio & -105.97 & -106.81 & -106.83 & -107.02 \\
\hline
\end{tabular}

- Significant at the 1 percent level.

- * Significant at the 5 percent level.

Note: Standard errors are in parentheses.

a. Lagged values are used for all variables except the terms of trade and the ratio of government consumption to GDP.

b. The contemporaneous U.S. real and nominal interest rates are used to instrument for the real and nominal interest rate.

c. The contemporaneous U.S. nominal interest rate is used to instrument for the nominal interest rate.

Source: Author's calculations based on information in the World Bank's World Saving Database.

real interest rate variable from equation $3 a$, as in equation $3 b$, lowers the $p$-value for the real exchange rate from 0.19 to 0.036 .

The implication is that both the intertemporal reallocation of consumption expenditures in response to changes in intertemporal relative prices and wealth effects were operative in generating the booms observed in this sample. The reallocation of consumption expenditures, however, is more likely to have worked through anticipated future increases in the price of consumer durables with a large imported component (as in the Dornbusch hypothesis) rather than through interest rate effects, either real or nominal. Similarly, wealth effects have generated booms more often when such effects were produced by improvements in the economy's terms of trade rather than by increases in the growth rate or by sectoral effects operating through the share of the economy's resources absorbed by the public sector.

These results, however, speak to the factors that have been associated most often with the emergence of booms and thus to the conditions under which booms are most likely to emerge. They cannot be interpreted as ruling out other mechanisms in driving specific episodes. In other words, we cannot, with these results, presume that all booms are alike. To examine the extent of uniformity in the 
factors driving booms, in the next section I consider the potential role that each of the mechanisms may have played in the individual booms included in the sample.

\section{EXPLAINING INDIVIDUAL BOOMS}

Explaining each boom-that is, measuring the empirical contribution of each potential causal variable to movements in the ratio of private consumption to GDP during each episode-is obviously beyond the scope of this article. Instead, I take up the more limited and logically prior question of whether the time-series behavior of the relevant macroeconomic variables during each boom is consistent with the hypotheses described above. In particular, I ask:

- Did domestic real interest rates fall at the inception of the boom?

- Was the emergence of the boom associated with a reduction and subsequent increase in the nominal interest rate?

- Did the boom accompany a major program of structural reform or a large change in the terms of trade, or was it followed by an acceleration of economic growth or by a fiscal consolidation that could be related to a revision in households' expectations of future income?

- Were there changes in the domestic financial system or in households' access to external financial markets that were consistent with a financeinduced boom? Such changes would involve not just financial liberalization but also, as indicated above, an approach to liberalization that may have encouraged imprudent behavior on the part of lenders.

Detecting the appropriate change in the macroeconomic variable emphasized by each hypothesis is a necessary, though not sufficient, condition to conclude that the hypothesis provides a valid explanation for the emergence of the boom. Further investigation would be required to establish its empirical relevance. If the postulated change did not occur, however, then the hypothesis cannot be sustained for the boom in question. In other words, this approach may permit us to rule out some explanations in individual cases, but it cannot identify the relative importance of surviving explanations. The objective is to expand the set of stylized facts about consumption booms by examining individual cases, while keeping the task to manageable proportions. I consider the alternative hypotheses one by one.

\section{Booms and Intertemporal Relative Prices}

The previous section linked the three boom hypotheses that rely on changes in intertemporal relative prices to the behavior of a specific macroeconomic variable. In order to account for the inception and end of the boom, each hypothesis implies a specific path for the relevant variable before, during, and after the boom. The Rodriguez hypothesis suggests that the real interest rate should fall during the boom and rise subsequently. The Dornbusch hypothesis implies that the real 
exchange rate should appreciate during the boom and be expected to depreciate subsequently. And the Calvo "temporariness" hypothesis suggests that the nominal exchange rate should fall during the boom and be expected to rise subsequently.

Since we cannot observe the expectations that operated during each of these episodes, I proxy them by the actual ex post behavior of the variable in question. Accordingly, in the discussion that follows I describe the behavior of the relevant variable during the boom episode as consistent with the hypothesis if its realized values follow the temporal pattern of the actual and expected future values that the hypothesis suggests.

Consider first the Rodríguez real interest rate mechanism. I examine the behavior of real interest rates around consumption booms for all of the booms in the sample for which I could extract market-determined interest rate data from the World Saving Database (table 3). Consistency in this case requires that the real interest rate be lower during the boom than both before and after the boom.

Overall, the real interest rate hypothesis does not fare well. For only two of the sample booms does the behavior of the real interest rate match that suggested by the Rodríguez hypothesis: Cyprus in 1991-92 and Zambia in 1987-90. In four

Table 3. Consumption Booms and Real Interest Rates

\begin{tabular}{lcrrrc}
\hline Country & Boom & Before & During & After & Consistent? \\
\hline Bangladesh & $1983-89$ & -0.72 & 1.60 & 5.03 & $\mathrm{~N}$ \\
Burundi & $1979-82$ & -8.58 & -7.96 & -1.61 & $\mathrm{~N}$ \\
Canada & $1960-63$ & - & 0.00 & 3.50 & $?$ \\
Chile & $1978-81$ & -51.25 & 10.08 & 11.30 & $\mathrm{~N}$ \\
Côte d'Ivoire & $1976-77$ & - & -10.21 & -6.60 & $?$ \\
Cyprus & $1991-92$ & 1.67 & 0.16 & 1.15 & $\mathrm{Y}$ \\
Denmark & $1975-79$ & -1.35 & 1.42 & 4.76 & $\mathrm{~N}$ \\
Gambia, The & $1984-85$ & 0.27 & -9.40 & -16.24 & $\mathrm{~N}$ \\
Iceland & $1970-74$ & - & -100.00 & 0.50 & $?$ \\
& $1987-88$ & -6.46 & -1.28 & 0.03 & $\mathrm{~N}$ \\
Indonesia & $1981-87$ & -8.16 & 2.75 & 10.73 & $\mathrm{~N}$ \\
Ireland & $1978-81$ & -8.46 & -4.03 & -1.14 & $\mathrm{~N}$ \\
Jamaica & $1987-90$ & -2.92 & 6.93 & -7.38 & $\mathrm{~N}$ \\
Malaysia & $1978-85$ & -2.11 & 0.95 & 2.91 & $\mathrm{~N}$ \\
Mexico & $1989-94$ & -14.45 & 3.93 & -57 & $\mathrm{~N}$ \\
Netherlands & $1975-83$ & -0.01 & 0.90 & 4.87 & $\mathrm{~N}$ \\
Nigeria & $1978-86$ & -9.51 & -8.03 & -11.50 & $\mathrm{~N}$ \\
Norway & $1975-77$ & -1.26 & -0.99 & 1.15 & $\mathrm{~N}$ \\
& $1985-88$ & 2.63 & 6.00 & 7.87 & $\mathrm{~N}$ \\
Portugal & $1971-78$ & - & -5.44 & 0.51 & $?$ \\
Sri Lanka & $1980-83$ & -1.11 & 2.80 & 6.53 & $\mathrm{~N}$ \\
Turkey & $1982-86$ & -38.58 & 4.84 & -6.37 & $\mathrm{~N}$ \\
Zambia & $1987-90$ & -21.81 & -37.61 & 45.79 & $\mathrm{Y}$ \\
Zimbabwe & $1978-83$ & -7.03 & -5.14 & -3.03 & $\mathrm{~N}$ \\
\hline
\end{tabular}

- Not available.

Note: $\mathrm{Y}$ indicates a lower real interest rate during the boom than either before or after the boom, ? corresponds to a lower real interest rate during the boom than before, or a higher real interest rate after the boom than during it, and no data are available for the other period. All other cases are labeled $\mathbf{N}$.

Source: Author's calculations based on information in the World Bank's World Saving Database. 
other cases-Canada, Côte d'Ivoire, Iceland, and Portugal-no data were available to confirm a reduction in the real interest rate during the boom, but the real interest rate did increase after the boom. The temporal pattern in the data did not match that predicted by the hypothesis in 18 of 24 cases.

The temporariness hypothesis requires that the nominal interest rate fall during the boom and rise subsequently. None of the boom episodes in the table clearly fits this pattern (table 4). Post-boom developments are often consistent with the postulated time path of the nominal interest rate (which increased after the boom in 16 of the 24 cases), but the nominal interest rate does not drop in any of the cases for which data are available, making it difficult to account for the timing of the boom's emergence using this mechanism. In three cases, however, the hypothesis cannot be ruled out, because of the absence of data. Overall, the predicted temporal pattern is rejected in 21 of 24 cases. For the most part, then, the evidence does not suggest that a large number of booms have emerged as a consequence of movements in nominal interest rates. The mechanism may be important in the context for which the hypothesis was intended (exchange rate-

Table 4. Consumption Booms and Nominal Interest Rates

\begin{tabular}{lcrrrc}
\hline Country & Boom & Before & During & After & Consistent? \\
\hline Bangladesh & $1983-89$ & 8.57 & 12.00 & 9.00 & $\mathrm{~N}$ \\
Burundi & $1979-82$ & 3.00 & 4.00 & 5.25 & $\mathrm{~N}$ \\
Chile & $1978-81$ & 95.00 & 47.00 & 34.25 & $\mathrm{~N}$ \\
Côte d'Ivoire & $1976-77$ & - & 7.00 & 7.50 & $?$ \\
Cyprus & $1991-92$ & 6.00 & 6.00 & 6.00 & $\mathrm{~N}$ \\
Denmark & $1975-79$ & 9.00 & 11.60 & 14.80 & $\mathrm{~N}$ \\
Gambia, The & $1984-85$ & 9.00 & 9.50 & 16.00 & $\mathrm{~N}$ \\
Iceland & $1970-74$ & - & 14.50 & 26.40 & $?$ \\
& $1987-88$ & 18.50 & 21.00 & 18.00 & $\mathrm{~N}$ \\
Indonesia & $1981-87$ & 9.00 & 12.00 & 19.40 & $\mathrm{~N}$ \\
Ireland & $1978-81$ & 8.00 & 10.00 & 9.25 & $\mathrm{~N}$ \\
Jamaica & $1987-90$ & 16.25 & 20.5 & 33 & $\mathrm{~N}$ \\
Malaysia & $1978-85$ & 3.50 & 5.63 & 5.75 & $\mathrm{~N}$ \\
Mauritania & $1982-84$ & 6.00 & 6.00 & 6.67 & $\mathrm{~N}$ \\
Mexico & $1989-94$ & 68.00 & 21.33 & 16.00 & $\mathrm{~N}$ \\
Netherlands & $1975-83$ & 6.11 & 7.11 & 6.67 & $\mathrm{~N}$ \\
Nigeria & $1978-86$ & 3.00 & 6.67 & 16.25 & $\mathrm{~N}$ \\
Norway & $1975-77$ & 6.67 & 8.33 & 9.33 & $\mathrm{~N}$ \\
& $1985-88$ & 12.75 & 13.50 & 11.75 & $\mathrm{~N}$ \\
Portugal & $1971-78$ & - & 13.67 & 21.75 & $?$ \\
Sri Lanka & $1980-83$ & 10.50 & 20.25 & 15.50 & $\mathrm{~N}$ \\
Turkey & $1982-86$ & 10.80 & 46.20 & 49.60 & $\mathrm{~N}$ \\
Zambia & $1987-90$ & 13.25 & 19.25 & 124.00 & $\mathbf{N}$ \\
Zimbabwe & $1978-83$ & 4.00 & 6.33 & 9.00 & $\mathrm{~N}$ \\
\hline
\end{tabular}

- Not available.

Note: $\mathrm{Y}$ indicates that the nominal interest rate falls during the boom and rises after, ? indicates that the nominal interest rate rises after the boom, and there are no data before the boom, while $\mathrm{N}$ indicates all other cases.

Source: Author's calculations based on information in the World Bank's World Saving Database. 
based stabilization in high-inflation countries), but it seems to have limited applicability outside of that setting.

Finally, to determine whether an anticipated future increase in the real price of durables may have played a role in triggering some of the consumption booms in the data, I examine the extent to which booms have been associated with a transitory appreciation of the real exchange rate. Unfortunately, data for real effective exchange rates-taken from the International Monetary Fund's trade-weighted series-are only available for a sufficiently large group of countries after 1979, limiting the sample of booms that could be examined for consistency with the Dornbusch hypothesis.

The Dornbusch hypothesis also fails to find strong support in the data, but it fares somewhat better than the two preceding hypotheses (table 5). The available data are consistent with the predicted temporal pattern in 9 of the 22 cases. In the remaining 13 episodes the real exchange rate either depreciated during the boom or appreciated after the boom. Both events are inconsistent with the emergence of a boom as the result of a temporary real appreciation. However, using a uniform standard for all three hypotheses, the incidence of inconsistency is much lower for this hypothesis than for the preceding ones.

Table 5. Consumption Booms and Real Appreciation

\begin{tabular}{lrrrrc}
\hline Country & Boom & Before & During & After & Consistent? \\
\hline Bangladesh & $1983-89$ & 109.77 & 107.41 & 94.31 & $\mathrm{~N}$ \\
Burundi & $1979-82$ & - & 148.16 & 169.36 & $\mathrm{~N}$ \\
Cape Verde & $1976-80$ & - & 87.50 & 98.64 & $\mathrm{~N}$ \\
Chile & $1978-81$ & - & 201.99 & 173.13 & $?$ \\
Cyprus & $1991-92$ & 101.06 & 101.29 & 104.35 & $\mathrm{~N}$ \\
Denmark & $1975-79$ & - & 100.89 & 89.43 & $?$ \\
Gambia, The & $1984-85$ & 128.96 & 126.91 & 97.06 & $\mathrm{~N}$ \\
Iceland & $1987-88$ & 98.10 & 108.28 & 100.54 & $\mathrm{Y}$ \\
Indonesia & $1981-87$ & 198.75 & 183.72 & 100.04 & $\mathrm{~N}$ \\
lreland & $1978-81$ & - & 87.51 & 94.66 & $\mathrm{~N}$ \\
Jamaica & $1987-90$ & 117.28 & 104.83 & 85.54 & $\mathrm{~N}$ \\
Malaysia & $1978-85$ & - & 142.80 & 107.38 & $?$ \\
Mauritania & $1982-84$ & 130.54 & 148.06 & 122.42 & $\mathrm{Y}$ \\
Mexico & $1989-94$ & 93.83 & 112.68 & 81.94 & $\mathrm{Y}$ \\
Netherlands & $1975-83$ & - & 106.04 & 100.11 & $?$ \\
Nigeria & $1978-86$ & - & 456.83 & 104.84 & $?$ \\
Norway & $1985-88$ & 100.40 & 99.22 & 98.58 & $\mathrm{~N}$ \\
Sri Lanka & $1980-83$ & 98.79 & 122.53 & 124.55 & $\mathrm{~N}$ \\
Sudan & $1977-85$ & - & 43.62 & 61.87 & $\mathrm{~N}$ \\
Turkey & $1982-86$ & 122.56 & 101.26 & 90.13 & $\mathrm{~N}$ \\
Zambia & $1987-90$ & 108.65 & 94.55 & 95.36 & $\mathrm{~N}$ \\
Zimbabwe & $1978-83$ & - & 160.25 & 132.05 & $?$ \\
\hline
\end{tabular}

- Not available.

Note: $\mathrm{Y}$ indicates real appreciation during the boom, while ? indicates real depreciation after the boom, and no data before the boom. All other cases are labeled N.

Source: Author's calculations based on information in the World Bank's World Saving Database. 
Overall, none of the mechanisms that rely on changes in intertemporal relative prices appears to offer promising explanations for a large number of consumption booms. Consistent with the results of the probit estimation, neither of the interest rate-based hypotheses fares well in the examination of individual booms. They may be important in particular circumstances, as in the case of incredible stabilizations, but the triggers for the majority of the consumption booms uncovered in the data appear to lie elsewhere. The results for the Dornbusch hypothesis are more favorable, again consistent with the probit estimates, but its applicability is clearly less than general.

\section{The "Euphoria" Factor in Consumption Booms}

Unfortunately, the relationship between the wealth variables and consumption booms is not straightforward. Theory suggests that a permanent improvement in the terms of trade, for example, should increase the ratio of private consumption to GDP, but it should do so permanently and not result in a transitory consumption boom. On the other hand, a transitory improvement in the terms of trade should have a minimal impact on the ratio of consumption to GDP. The same reasoning applies to the other variables that may increase private consumption through wealth effects-although they may account for a one-time change in the consumption-income ratio, they would not in general produce transitory consumption swings of the type associated with booms in this sample. A possible explanation concerns the role of consumer durables. Since what is measured in the data is consumption expenditures, rather than consumption itself, an adjustment in the stock of durables in response to a perceived increase in household wealth could, in principle, trigger an overshooting in consumer expenditures.

Accordingly, the standards of consistency are somewhat looser in this section than in the previous one. Here I judge the data to be consistent with each wealth hypothesis if the hypothesis can account for the increase in the ratio of consumption to GDP during the boom, without requiring it also to explain why the boom ended. In the case of a change in the terms of trade, for example, the emergence of a consumption boom is taken to be consistent with an explanation relying on a perceived permanent improvement in the terms of trade if the terms of trade improved during the boom and were, on average, more favorable during and after the boom than before the boom. I employ similar criteria for the other two variables considered in this section, the growth rate of real GDP and the share of public consumption in GDP. According to this criterion, a terms of trade explanation is consistent with the evidence for 22 of the 38 cases for which complete data are available (table 6). In 3 of the 16 cases that are rejected (Portugal, Sudan, and Togo), the terms of trade improved during the boom, but deteriorated subsequently by an amount sufficient to make the average terms of trade less favorable during and immediately after the boom than before the boom. Overall, it is clear that booms have routinely been accompanied by improvements in the terms of trade. Since there is no question of reverse causality for the countries in this 
Table 6. Consumption Booms and Terms of Trade Shocks

\begin{tabular}{|c|c|c|c|c|c|}
\hline Country & Boom & Before & Durring & After & Consistent? \\
\hline Bangladesh & 1983-89 & 0.85 & 1.00 & 0.96 & $\mathbf{Y}$ \\
\hline \multirow[t]{2}{*}{ Burundi } & $1961-63$ & 1.38 & 1.38 & 1.30 & $\mathbf{N}$ \\
\hline & $1979-82$ & 1.97 & 1.25 & 1.18 & $\mathbf{N}$ \\
\hline Cape Verde & $1976-80$ & 0.37 & 0.71 & 1.00 & $\mathbf{Y}$ \\
\hline Chile & $1978-81$ & 1.35 & 1.14 & 0.97 & $\mathbf{N}$ \\
\hline Costa Rica & $1964-71$ & 1.19 & 1.12 & 0.98 & $\mathbf{N}$ \\
\hline \multirow[t]{2}{*}{ Côte d'Ivoire } & $1969-70$ & 1.13 & 1.51 & 1.15 & $\mathbf{Y}$ \\
\hline & $1976-77$ & 1.22 & 1.74 & 1.73 & $\mathbf{Y}$ \\
\hline Cyprus & 1991-92 & 0.96 & 0.98 & 0.99 & Y \\
\hline Denmark & $1975-79$ & 1.15 & 1.07 & 0.95 & $\mathbf{N}$ \\
\hline Gambia, The & $1984-85$ & 0.82 & 0.93 & 1.02 & $\mathbf{Y}$ \\
\hline Guinea-Bissau & $1971-75$ & 0.14 & 0.61 & 0.44 & $\mathbf{Y}$ \\
\hline Honduras & $1976-77$ & 0.97 & 1.29 & 1.22 & $\mathbf{Y}$ \\
\hline \multirow[t]{2}{*}{ Iceland } & $1970-74$ & 0.87 & 1.01 & 0.99 & $\mathbf{Y}$ \\
\hline & $1987-88$ & 0.93 & 1.00 & 0.94 & $\mathbf{Y}$ \\
\hline Indonesia & $1981-87$ & 0.75 & 1.17 & 0.92 & $\mathbf{Y}$ \\
\hline Ireland & 1978-81 & 1.01 & 0.96 & 0.96 & $\mathbf{N}$ \\
\hline Jamaica & $1987-90$ & 0.77 & 1.02 & 0.72 & $\mathbf{Y}$ \\
\hline Lesotho & $1975-77$ & 1.06 & 1.54 & 1.22 & $\mathbf{Y}$ \\
\hline Malaysia & $1978-85$ & 0.94 & 1.08 & 1.01 & $\mathbf{Y}$ \\
\hline \multirow[t]{2}{*}{ Mauritania } & $1973-77$ & 0.97 & 1.24 & 0.97 & $\mathbf{Y}$ \\
\hline & $1982-84$ & 0.93 & 0.98 & 1.07 & $\mathbf{Y}$ \\
\hline Mexico & $1989-94$ & 1.11 & 1.07 & 0.99 & $\mathbf{N}$ \\
\hline Netherlands & $1975-83$ & 1.07 & 1.02 & 1.01 & $\mathbf{N}$ \\
\hline New Zealand & $1972-75$ & 1.00 & 1.08 & 0.93 & $\mathbf{Y}$ \\
\hline Nigeria & $1978-86$ & 0.95 & 1.99 & 0.86 & $\mathbf{Y}$ \\
\hline \multirow[t]{2}{*}{ Norway } & $1975-77$ & 1.26 & 1.15 & 1.17 & $\mathbf{N}$ \\
\hline & $1985-88$ & 1.31 & 1.08 & 0.99 & $\mathbf{N}$ \\
\hline Paraguay & $1962-69$ & 0.70 & 0.91 & 1.02 & $\mathbf{Y}$ \\
\hline Portugal & $1971-78$ & 0.96 & 1.02 & 0.89 & $\mathbf{N}$ \\
\hline Sri Lanka & $1980-83$ & 1.41 & 0.99 & 1.00 & $N$ \\
\hline Sudan & $1977-85$ & 0.98 & 1.21 & 0.76 & $\mathbf{N}$ \\
\hline Togo & $1966-70$ & 1.58 & 1.78 & 0.96 & $\mathbf{N}$ \\
\hline Turkey & $1982-86$ & 0.86 & 1.02 & 0.96 & $\mathbf{Y}$ \\
\hline Uruguay & $1969-75$ & 1.28 & 1.29 & 0.88 & $\mathbf{N}$ \\
\hline \multirow[t]{2}{*}{ Zambia } & $1966-70$ & 1.41 & 2.24 & 1.59 & $\mathbf{Y}$ \\
\hline & $1987-90$ & 0.69 & 0.92 & 0.57 & $\mathbf{N}$ \\
\hline Zimbabwe & $1978-83$ & 0.35 & 1.06 & 1.05 & $\mathbf{Y}$ \\
\hline
\end{tabular}

Note: $Y$ indicates that the terms of trade improve during the boom and are more favorable on average during and after the boom than before, and $N$ refers to all other cases.

Sowrce: Author's calculations based on information in the World Bank's World Saving Database.

sample, the suggestion is strong that improvements in the terms of trade often have contributed to the emergence of consumption booms.

The criterion for consistency of the growth rate of real output is that the growth rate accelerated during the boom, and the average growth rate during and after the boom exceeded the average growth rate before the boom (table 7). The first point to notice is that booms are not always accompanied by an acceleration of economic growth. Indeed, the growth rate fell during the boom in 17 of the 35 episodes for which it is possible to make the comparison. In 9 of the 35 booms 
Table 7. Consumption Booms and Economic Growth

\begin{tabular}{|c|c|c|c|c|c|}
\hline Country & Boom & Before & During & After & Consistent? \\
\hline Bangladesh & $1983-89$ & 4.02 & 3.97 & 4.30 & $\mathbf{N}$ \\
\hline Burundi & $1979-82$ & 4.92 & 1.52 & 3.94 & $\mathbf{N}$ \\
\hline Cape Verde & $1976-80$ & -3.08 & 7.14 & 13.64 & $\mathbf{Y}$ \\
\hline Chile & $1978-81$ & -3.63 & 7.31 & -2.00 & $\mathbf{Y}$ \\
\hline Costa Rica & $1964-71$ & 0.76 & 6.73 & 6.07 & $\mathbf{Y}$ \\
\hline \multirow[t]{2}{*}{ Côte d'Ivoire } & $1969-70$ & 9.51 & 10.49 & 4.76 & $\mathbf{N}$ \\
\hline & $1976-77$ & 9.14 & 3.85 & 6.68 & $\mathbf{N}$ \\
\hline Cyprus & $1991-92$ & 8.39 & 3.88 & 5.45 & $\mathbf{N}$ \\
\hline Denmark & $1975-79$ & 3.90 & 1.39 & 1.13 & $\mathbf{N}$ \\
\hline Gambia, The & $1984-85$ & 11.27 & -3.34 & 0.29 & $\mathbf{N}$ \\
\hline Honduras & $1976-77$ & 4.60 & 4.81 & 10.46 & $Y$ \\
\hline \multirow[t]{2}{*}{ Iceland } & $1970-74$ & 3.75 & 7.20 & 5.22 & $\mathbf{Y}$ \\
\hline & $1987-88$ & 3.68 & 8.27 & -0.56 & $\mathbf{N}$ \\
\hline Indonesia & $1981-87$ & 7.22 & 6.01 & 7.74 & $\mathbf{N}$ \\
\hline Ireland & $1978-81$ & 3.45 & 4.60 & 0.77 & $\mathbf{N}$ \\
\hline Jamaica & $1987-90$ & -2.52 & 6.56 & 4.41 & $\mathbf{Y}$ \\
\hline Lesotho & $1975-77$ & 15.79 & 11.79 & 8.68 & $\mathbf{N}$ \\
\hline Malaysia & $1978-85$ & 7.12 & 6.78 & 6.38 & $\mathbf{N}$ \\
\hline \multirow{2}{*}{ Mauritania } & $1973-77$ & 4.24 & 1.86 & 2.83 & $\mathbf{N}$ \\
\hline & $1982-84$ & 3.43 & 2.31 & -0.21 & $\mathbf{N}$ \\
\hline Mexico & $1989-94$ & 0.24 & 3.91 & - & $?$ \\
\hline Netherlands & $1975-83$ & 4.88 & 1.65 & 2.90 & $\mathbf{N}$ \\
\hline New Zealand & $1972-75$ & 1.10 & 5.61 & -1.20 & $\mathbf{N}$ \\
\hline Nigeria & $1978-86$ & 8.35 & 0.32 & 4.01 & $\mathbf{N}$ \\
\hline \multirow[t]{2}{*}{ Norway } & $1975-77$ & 4.50 & 5.11 & 3.50 & $\mathbf{N}$ \\
\hline & $1985-88$ & 2.69 & 4.86 & 0.98 & $\mathbf{N}$ \\
\hline Portugal & $1971-78$ & 6.28 & 5.26 & 1.59 & $\mathbf{N}$ \\
\hline Sri Lanka & $1980-83$ & 5.14 & 6.08 & 4.50 & $\mathbf{N}$ \\
\hline Sudan & $1977-85$ & 2.70 & 3.07 & 2.33 & $\mathrm{~N}$ \\
\hline Togo & $1966-70$ & 9.45 & 8.37 & 4.40 & $\mathrm{~N}$ \\
\hline Turkey & $1982-86$ & 2.22 & 4.74 & 5.68 & $\mathbf{Y}$ \\
\hline Uruguay & $1969-75$ & 2.24 & 0.25 & 4.84 & $\mathbf{N}$ \\
\hline \multirow[t]{2}{*}{ Zambia } & $1966-70$ & 3.11 & 6.51 & 3.80 & $\mathrm{Y}$ \\
\hline & $1987-90$ & -3.27 & 2.57 & 1.40 & $\mathrm{Y}$ \\
\hline Zimbabwe & $1978-83$ & 3.96 & 3.14 & 3.04 & $\mathbf{N}$ \\
\hline
\end{tabular}

- Not available.

Note: $Y$ indicates that growth increases during the boom and is greater on average during and after the boom than before; ? indicates that growth increases during the boom and no data are available for the period after the boom. All other cases are denoted $N$.

Source: Author's calculations based on information in the World Bank's World Saving Dacabase.

for which data are available, the evidence is consistent with wealth effects from current and anticipated future economic growth driving the booms. Reverse causation could play a role here, since the emergence of a private consumption boom could stimulate growth during the boom through expansionary effects on aggregate demand. Nonetheless, this is unlikely to be all of the story, since the growth rate after the boom exceeded that before the boom in the nine cases judged to be consistent with the wealth hypothesis.

In short, for many countries the data are consistent with the hypothesis that booms are driven by wealth effects operating at the national level, in the form of 
favorable movements in the terms of trade. An anticipated acceleration in the rate of economic growth also may have played a role, but in many fewer episodes.

The final wealth mechanism explored here operates at the sectoral level, reflecting the potentially favorable effects on private wealth of an anticipated future fiscal consolidation, which takes the form of a reduction in the share of public consumption in GDP. The criterion used to judge consistency in this case is the same as that for the other applications-to be judged consistent with the hypothesis, the ratio of public consumption to GDP must fall during the boom and remain, on average, below its pre-boom level during and after the boom. In only a few cases -4 of the 37 booms with the requisite data - are the data consistent with an anticipated fiscal consolidation (table 8).

Overall, then, the data from individual booms suggest that wealth effects are a more promising avenue for understanding the origins of consumption booms than effects operating through intertemporal relative prices, although the latter may be important in specific circumstances. Current and anticipated increases in the terms of trade may have generated wealth effects that triggered consumption booms in nearly two-thirds of the episodes in the sample. The evidence is substantially weaker for anticipated acceleration in economic growth or anticipated fiscal consolidation.

\section{Financial Policies: Booms and Rapid Credit Expansion}

To consider the potential empirical role of credit expansion in the generation of consumption booms, I examine the extent to which the booms in the sample were associated with an increase in the ratio of the flow of domestic credit to the private sector to GDP. I compute average ratios for periods of equal length before, during, and after each of the consumption booms identified previously (table 9). I judge the data to be consistent with the hypothesis that booms are driven by rapid credit expansion if credit expansion accelerated during the boom and decelerated after the boom.

Of the 31 booms in this sample, in 22 the ratio of the flow of credit to the private sector to GDP increased from the period before the boom to the period during the boom, sometimes dramatically. More impressive is the fact that in $\mathbf{1 2}$ of these 22 cases (marked as "consistent" in table 9) the acceleration of credit expansion during the boom was followed by deceleration after the boom, suggesting a role for credit in both starting and ending the boom. Still, although lending booms may have been important in a substantial minority of the cases, the predicted temporal association with consumption booms failed to emerge in two-thirds of all cases. ${ }^{6}$

6. This result may arise in part from the particular credit variable used in the exercise. I use credit to the private sector to proxy for the more appropriate (but unavailable) variable, credit to households. To the extent that lending booms reflect a redirection of credit from firms to households without a corresponding expansion of credit to the private sector as a whole, their role in triggering consumption booms would not be revealed through the use of this proxy. 
Table 8. Consumption Booms and Public Sector Consumption

\begin{tabular}{|c|c|c|c|c|c|}
\hline Country & Boom & Before & Durring & After & Consistent? \\
\hline \multirow[t]{2}{*}{ Burundi } & $1961-63$ & 0.03 & 0.04 & 0.08 & $\mathbf{N}$ \\
\hline & $1979-82$ & 0.13 & 0.11 & 0.10 & $\mathrm{Y}$ \\
\hline Cape Verde & $1976-80$ & 0.08 & 0.11 & 0.22 & $\mathbf{N}$ \\
\hline Chile & $1978-81$ & 0.17 & 0.14 & 0.13 & $\mathbf{Y}$ \\
\hline Costa Rica & $1964-71$ & 0.15 & 0.16 & 0.16 & $\mathbf{N}$ \\
\hline \multirow[t]{2}{*}{ Côte d'Ivoire } & $1969-70$ & 0.11 & 0.13 & 0.16 & $\mathbf{N}$ \\
\hline & $1976-77$ & 0.17 & 0.19 & 0.20 & $\mathbf{N}$ \\
\hline Cyprus & $1991-92$ & 0.17 & 0.18 & 0.15 & $\mathbf{N}$ \\
\hline Denmark & $1975-79$ & 0.23 & 0.25 & 0.27 & $\mathbf{N}$ \\
\hline Gambia, The & $1984-85$ & 0.20 & 0.15 & 0.28 & $\mathbf{N}$ \\
\hline Guinea-Bissau & $1971-75$ & 0.10 & 0.11 & 0.10 & $\mathbf{N}$ \\
\hline Honduras & $1976-77$ & 0.13 & 0.14 & 0.12 & $\mathbf{N}$ \\
\hline \multirow[t]{2}{*}{ Iceland } & $1970-74$ & 0.14 & 0.16 & 0.17 & $\mathbf{N}$ \\
\hline & $1987-88$ & 0.19 & 0.19 & 0.20 & $\mathbf{N}$ \\
\hline Indonesia & $1981-87$ & 0.08 & 0.10 & 0.09 & $\mathbf{N}$ \\
\hline Ireland & $1978-81$ & 0.19 & 0.19 & 0.19 & $\mathbf{N}$ \\
\hline Jamaica & $1987-90$ & 0.10 & 0.15 & 0.12 & $\mathbf{N}$ \\
\hline Lesotho & $1975-77$ & 0.11 & 0.14 & 0.18 & $\mathbf{N}$ \\
\hline Malaysia & $1978-85$ & 0.15 & 0.17 & 0.15 & $\mathbf{N}$ \\
\hline \multirow[t]{2}{*}{ Mauritania } & $1973-77$ & 0.14 & 0.29 & 0.26 & $\mathbf{N}$ \\
\hline & $1982-84$ & 0.25 & 0.18 & 0.14 & $\mathbf{Y}$ \\
\hline Mexico & $1989-94$ & 0.08 & 0.08 & - & $\mathbf{N}$ \\
\hline Netherlands & $1975-83$ & 0.15 & 0.15 & 0.15 & $\mathbf{N}$ \\
\hline New Zealand & $1972-75$ & 0.16 & 0.16 & 0.17 & $\mathbf{N}$ \\
\hline Nigeria & $1978-86$ & 0.12 & 0.17 & 0.13 & $\mathbf{N}$ \\
\hline \multirow[t]{2}{*}{ Norway } & $1975-77$ & 0.19 & 0.19 & 0.19 & $\mathbf{N}$ \\
\hline & $1985-88$ & 0.21 & 0.20 & 0.21 & $\mathbf{N}$ \\
\hline Paraguay & $1962-69$ & 0.02 & 0.08 & 0.11 & $\mathbf{N}$ \\
\hline Portugal & $1971-78$ & 0.08 & 0.10 & 0.13 & $\mathbf{N}$ \\
\hline Sri Lanka & $1980-83$ & 0.12 & 0.11 & 0.13 & $\mathbf{N}$ \\
\hline Sudan & $1977-85$ & 0.18 & 0.12 & 0.12 & $\mathbf{Y}$ \\
\hline Togo & $1966-70$ & 0.14 & 0.13 & 0.16 & $\mathbf{N}$ \\
\hline Turkey & $1982-86$ & 0.07 & 0.07 & 0.08 & $\mathbf{N}$ \\
\hline Uruguay & $1969-75$ & 0.10 & 0.10 & 0.11 & $\mathbf{N}$ \\
\hline \multirow[t]{2}{*}{ Zambia } & $1966-70$ & 0.16 & 0.22 & 0.30 & $\mathbf{N}$ \\
\hline & $1987-90$ & 0.26 & 0.21 & 0.29 & $\mathbf{N}$ \\
\hline Zimbabwe & $1978-83$ & 0.10 & 0.19 & 0.26 & $\mathbf{N}$ \\
\hline
\end{tabular}

- Not available.

Note: $\mathrm{Y}$ indicates that the share of public consumption falls during the boom and is lower on average during and after the boom than before, and $\mathrm{N}$ denotes all other cases.

Source: Author's calculations based on information in the World Bank's World Saving Database.

The conclusion that financial sector developments, either in the form of domestic policies or external financial shocks, may have played a role in triggering a significant number of booms must be tempered by the strong likelihood of reverse causation in this case. Booms emerging for other reasons obviously could result in greater private demand for credit, which would appear as an increase in the ratio of the flow of credit to the private sector to GDP. This possibility seems more likely in this case than in that of the other hypotheses examined. It also is consistent with 
Table 9. Consumption Booms and Credit Expansion

\begin{tabular}{|c|c|c|c|c|c|}
\hline Country & Boom & Before & During & After & Consistent? \\
\hline Bangladesh & 1983-89 & 0.017 & 0.034 & 0.021 & $Y$ \\
\hline Burundi & $1979-82$ & 0.003 & 0.027 & -0.007 & $\mathrm{Y}$ \\
\hline Cape Verde & $1976-80$ & 0.084 & 0.073 & 0.094 & $\mathbf{N}$ \\
\hline Chile & 1978-81 & 0.077 & 0.162 & 0.183 & $\mathbf{N}$ \\
\hline Costa Rica & $1964-71$ & 0.084 & 0.073 & 0.094 & $\mathbf{N}$ \\
\hline \multirow[t]{2}{*}{ Côte d'Ivoire } & $1969-70$ & 0.019 & 0.036 & 0.038 & $\mathrm{~N}$ \\
\hline & $1976-77$ & 0.084 & 0.073 & 0.094 & $\mathbf{N}$ \\
\hline Cyprus & $1991-92$ & 0.084 & 0.095 & 0.095 & $\mathbf{N}$ \\
\hline Denmark & $1975-79$ & 0.054 & 0.047 & 0.031 & $\mathbf{N}$ \\
\hline Gambia, The & $1984-85$ & 0.006 & 0.044 & 0.018 & $\mathbf{Y}$ \\
\hline Honduras & $1976-77$ & 0.032 & 0.042 & 0.031 & $\mathrm{Y}$ \\
\hline \multirow[t]{2}{*}{ Iceland } & $1970-74$ & 0.042 & 0.052 & 0.079 & $\mathbf{N}$ \\
\hline & $1987-88$ & 0.123 & 0.087 & 0.113 & $\mathbf{N}$ \\
\hline Indonesia & $1981-87$ & 0.050 & 0.026 & 0.086 & $N$ \\
\hline Ireland & $1978-81$ & 0.042 & 0.054 & 0.027 & $\mathbf{Y}$ \\
\hline Jamaica & $1987-90$ & 0.047 & 0.063 & 0.058 & $\mathbf{Y}$ \\
\hline Malaysia & $1978-85$ & 0.036 & 0.076 & 0.078 & $\mathbf{N}$ \\
\hline \multirow[t]{2}{*}{ Mauritania } & $1973-77$ & 0.025 & 0.053 & 0.033 & $\mathbf{Y}$ \\
\hline & $1982-84$ & 0.023 & 0.032 & 0.023 & $\mathbf{Y}$ \\
\hline Mexico & $1989-94$ & 0.041 & 0.076 & 0.119 & $\mathbf{N}$ \\
\hline Netherlands & $1975-83$ & 0.049 & 0.067 & 0.052 & $\mathbf{Y}$ \\
\hline New Zealand & $1972-75$ & 0.010 & 0.024 & 0.025 & $\mathbf{N}$ \\
\hline Nigeria & $1978-86$ & 0.012 & 0.021 & 0.026 & $\mathbf{N}$ \\
\hline \multirow[t]{2}{*}{ Norway } & $1975-77$ & 0.042 & 0.034 & 0.035 & $N$ \\
\hline & $1985-88$ & 0.040 & 0.104 & 0.024 & $\mathrm{Y}$ \\
\hline Portugal & $1971-78$ & 0.062 & 0.102 & 0.110 & $\mathbf{N}$ \\
\hline Sudan & $1977-85$ & 0.015 & 0.030 & 0.025 & $\mathbf{Y}$ \\
\hline Togo & $1966-70$ & 0.011 & 0.005 & 0.021 & $\mathbf{N}$ \\
\hline Turkey & $1982-86$ & 0.043 & 0.059 & 0.063 & $\mathbf{N}$ \\
\hline Uruguay & $1969-75$ & 0.065 & 0.061 & 0.128 & $\mathbf{N}$ \\
\hline Zambia & $1987-90$ & 0.031 & 0.058 & 0.044 & $\mathrm{Y}$ \\
\hline
\end{tabular}

Note: $\mathrm{Y}$ indicates that credit expansion was larger during the boom than both before and after, and $\mathrm{N}$ indicates all other cases.

Source: Author's calculations based on information in the World Bank's World Saving Database.

the results of the previous section, in which the availability of credit had no independent effect on the probability of a boom after accounting for other potential causal factors and in which the domestic credit variable reversed signs after feedback effects were ameliorated through the lagged specification.

An alternative, albeit crude, way to assess the potential role of domestic financial sector policies in generating booms is to examine how frequently financial crises follow consumption booms. Booms arising from excessive lending because of inappropriate financial sector policies are more likely to result eventually in a financial crisis than those arising from other sources.

Using a five-year post-boom window and taking the dating of crises from Caprio and Klingebiel (1997), I find that eight of the booms accompanied by rapid credit expansion were followed by financial crises-Bangladesh, Chile, Malaysia, 
Mauritania (1982-84), Mexico, Nigeria, Norway (1975-77), and Turkey. None of the countries with booms that were classified as inconsistent with the credit expansion hypothesis experienced a crisis within the five-year window. This procedure is obviously highly imperfect, since crises can have many other causes, and the incidence and timing of a financial crisis after an episode of excessive lending can depend on many factors. But it at least suggests that the coincidence of consumption booms and credit expansion in table 9 may not reflect reverse causation in every case.

\section{SUMMARY AND CONCLUSIONS}

The evidence compiled in the last section examined the potential driving forces of consumption booms one at a time. Tables 10 and 11 bring this information together for all of the consumption booms in the sample. The following conclusions follow from these tables, as well as from the material in sections II and III.

Consumption booms are not all driven by the same factors. No single explanation appears to dominate for all, or even for a significant majority, of the booms in the sample. As expected, booms arise in a wide variety of macroeconomic circumstances. Nonetheless, some hypotheses seem more applicable than others. Booms appear to be associated most commonly with long-lasting improvements in the terms of trade. The terms of trade variable is statistically significant in each of the probit regressions, and a large proportion of individual booms are associated with improvements in the terms of trade. This result is particularly significant because, given that the terms of trade are exogenous for the small countries involved, reverse causation is not an issue. The role of the

Table 10. Factors Driving Consumption Booms in Industrial Countries

\begin{tabular}{|c|c|c|c|c|c|c|c|c|}
\hline \multirow[b]{2}{*}{ Country } & \multirow[b]{2}{*}{ Booms } & \multicolumn{3}{|c|}{ Intertemporal relative prices } & \multicolumn{3}{|c|}{ Wealth } & \multirow[b]{2}{*}{$\begin{array}{c}\text { Credit } \\
\text { expansion }\end{array}$} \\
\hline & & $\begin{array}{c}\text { Real } \\
\text { interest } \\
\text { rate }\end{array}$ & $\begin{array}{c}\text { Nominal } \\
\text { interest } \\
\text { rate }\end{array}$ & $\begin{array}{c}\text { Real } \\
\text { exchange } \\
\text { rate }\end{array}$ & $\begin{array}{c}\text { Terms of } \\
\text { trade } \\
\text { shocks }\end{array}$ & $\begin{array}{l}G D P \\
\text { growth }\end{array}$ & $\begin{array}{c}\text { Public } \\
\text { sector } \\
\text { onsumption }\end{array}$ & \\
\hline Canada & $1960-63$ & $?$ & & & & & & \\
\hline Denmark & $1975-79$ & $\mathbf{N}$ & $\mathbf{N}$ & $?$ & $\mathrm{~N}$ & $\mathrm{~N}$ & $\mathbf{N}$ & $\mathbf{N}$ \\
\hline \multirow[t]{2}{*}{ Iceland } & $1970-74$ & $?$ & $?$ & & $\mathbf{Y}$ & $\mathbf{Y}$ & $\mathbf{N}$ & $\mathbf{N}$ \\
\hline & $1987-88$ & $\mathbf{N}$ & & $\mathbf{Y}$ & $\mathbf{Y}$ & $\mathbf{N}$ & $\mathbf{N}$ & $\mathbf{N}$ \\
\hline Ireland & $1978-81$ & $\mathbf{N}$ & $\mathbf{N}$ & $\mathbf{N}$ & $\mathbf{N}$ & $\mathrm{N}$ & $\mathbf{N}$ & $\mathrm{Y}$ \\
\hline Netherlands & $1975-83$ & $\mathbf{N}$ & $\mathbf{N}$ & $?$ & $\mathbf{N}$ & $\mathbf{N}$ & $\mathbf{N}$ & Y \\
\hline New Zealand & $1972-75$ & & & & $\mathbf{Y}$ & $\mathbf{N}$ & $\mathbf{N}$ & $\mathbf{N}$ \\
\hline \multirow[t]{2}{*}{ Norway } & $1975-77$ & $\mathbf{N}$ & $\mathbf{N}$ & $\mathbf{N}$ & $\mathbf{N}$ & $\mathbf{N}$ & $\mathbf{N}$ & $\mathbf{N}$ \\
\hline & $1985-88$ & $\mathbf{N}$ & & $\mathbf{N}$ & $\mathbf{N}$ & $\mathbf{N}$ & $\mathbf{N}$ & $\mathbf{Y}$ \\
\hline Portugal & $1971-78$ & $?$ & ? & & $?$ & $\mathbf{N}$ & $\mathbf{N}$ & $\mathbf{N}$ \\
\hline
\end{tabular}

Note: $Y$ indicates that growth increases during the boom and is greater on average during and after the boom than before; ? indicates that growth increases during the boom and no data are available for the period after the boom. All other cases are denoted $\mathbf{N}$.

Source: Author's calculations based on information in the World Bank's World Saving Database. 
Table 11. Factors Driving Consumption Booms in Developing Countries

\begin{tabular}{|c|c|c|c|c|c|c|c|c|}
\hline \multirow[b]{2}{*}{ Country } & \multirow[b]{2}{*}{ Booms } & \multicolumn{3}{|c|}{ Intertemporal relative prices } & \multicolumn{3}{|c|}{ Wealth } & \multirow[b]{2}{*}{$\begin{array}{c}\text { Credit } \\
\text { expansion }\end{array}$} \\
\hline & & $\begin{array}{c}\text { Real } \\
\text { interest } \\
\text { rate }\end{array}$ & $\begin{array}{c}\text { Nominal } \\
\text { interest } \\
\text { rate }\end{array}$ & $\begin{array}{c}\text { Real } \\
\text { exchange } \\
\text { rate }\end{array}$ & $\begin{array}{c}\text { Terms of } \\
\text { trade } \\
\text { shocks }\end{array}$ & $\begin{array}{l}G D P \\
\text { growth } c\end{array}$ & $\begin{array}{c}\text { Public } \\
\text { sector } \\
\text { consumption }\end{array}$ & \\
\hline Bangladesh & $1983-89$ & $\mathbf{N}$ & $\mathbf{N}$ & $\mathbf{N}$ & $\mathbf{Y}$ & $\mathbf{N}$ & & $\mathbf{Y}$ \\
\hline \multirow{2}{*}{ Burundi } & $1961-63$ & & & & $\mathbf{N}$ & & $\mathbf{N}$ & \\
\hline & $1979-82$ & $\mathbf{N}$ & $\mathbf{N}$ & $\mathbf{N}$ & $\mathbf{N}$ & $\mathbf{N}$ & $\mathbf{Y}$ & $\mathbf{Y}$ \\
\hline Cape Verde & $1976-80$ & & $\mathbf{N}$ & & $\mathbf{Y}$ & $\mathbf{Y}$ & $\mathbf{N}$ & $\mathbf{N}$ \\
\hline Chile & $1978-81$ & $\mathbf{N}$ & $\mathbf{N}$ & $Y$ & $\mathbf{N}$ & $\mathrm{Y}$ & $\mathbf{N}$ & $\mathbf{N}$ \\
\hline Costa Rica & $1964-71$ & & & & $\mathbf{N}$ & $\mathrm{Y}$ & $\mathbf{N}$ & $\mathbf{N}$ \\
\hline \multirow[t]{2}{*}{ Côte d'Ivoire } & $1969-70$ & & & & $\mathbf{Y}$ & $\mathbf{N}$ & $\mathbf{N}$ & $\mathbf{N}$ \\
\hline & $1976-77$ & ? & $?$ & & $\mathrm{Y}$ & $\mathbf{N}$ & $\mathbf{N}$ & $\mathbf{N}$ \\
\hline Cyprus & 1991-92 & $\mathbf{Y}$ & $\mathbf{N}$ & $\mathbf{N}$ & $\mathbf{Y}$ & $\mathbf{N}$ & $\mathbf{N}$ & $\mathbf{N}$ \\
\hline Gambia, The & $1984-85$ & $\mathbf{N}$ & $\mathbf{N}$ & $\mathbf{N}$ & $\mathrm{Y}$ & $\mathbf{N}$ & $\mathbf{N}$ & $\mathbf{Y}$ \\
\hline Guinea-Bissau & $1971-75$ & . & & & $\mathbf{Y}$ & & $\mathbf{N}$ & \\
\hline Honduras & $1976-77$ & & & & $\mathbf{Y}$ & $\mathbf{Y}$ & $\mathbf{N}$ & $\mathbf{Y}$ \\
\hline Indonesia & $1981-87$ & $\mathbf{N}$ & $\mathbf{N}$ & $\mathbf{N}$ & $\mathbf{Y}$ & $\mathbf{N}$ & $\mathbf{N}$ & $\mathbf{N}$ \\
\hline Jamaica & $1987-90$ & $\mathbf{N}$ & $\mathbf{N}$ & $\mathbf{N}$ & $\mathbf{Y}$ & $\mathbf{Y}$ & $\mathbf{N}$ & $\mathbf{Y}$ \\
\hline Lesotho & $1975-77$ & & & & $\mathbf{Y}$ & $\mathbf{N}$ & $\mathbf{N}$ & \\
\hline Malaysia & $1978-85$ & $\mathbf{N}$ & $\mathbf{N}$ & $?$ & $\mathrm{Y}$ & $\mathbf{N}$ & $\mathbf{N}$ & $\mathbf{N}$ \\
\hline Mali & $1983-85$ & & & & & $\mathbf{N}$ & & \\
\hline \multirow[t]{2}{*}{ Mauritania } & $1973-77$ & & & & $\mathbf{Y}$ & $\mathbf{N}$ & $\mathbf{N}$ & Y \\
\hline & $1982-84$ & & $\mathbf{N}$ & $Y$ & $\mathbf{Y}$ & $\mathbf{N}$ & $\mathbf{Y}$ & $\mathbf{Y}$ \\
\hline Mexico & $1989-94$ & $\mathbf{N}$ & $\mathbf{N}$ & $Y$ & $\mathbf{N}$ & $?$ & $\mathbf{N}$ & $\mathbf{N}$ \\
\hline Nigeria & $1978-86$ & $\mathbf{N}$ & $\mathbf{N}$ & $?$ & $\mathrm{Y}$ & $\mathbf{N}$ & $\mathbf{N}$ & $\mathbf{N}$ \\
\hline Paraguay & $1962-69$ & & & & $\mathbf{Y}$ & & $\mathbf{N}$ & \\
\hline Sri Lanka & & $\mathbf{N}$ & $\mathbf{N}$ & $\mathbf{N}$ & $\mathbf{N}$ & $\mathbf{N}$ & $\mathbf{N}$ & \\
\hline Sudan & $1977-85$ & & & $\mathbf{N}$ & $?$ & $\mathbf{N}$ & $\mathbf{N}$ & $\mathrm{Y}$ \\
\hline Togo & $1966-70$ & & & & $?$ & $\mathbf{N}$ & $\mathbf{N}$ & $\mathbf{N}$ \\
\hline \multicolumn{9}{|l|}{ Trinidad and } \\
\hline Turkey & $1982-86$ & $\mathbf{N}$ & $\mathbf{N}$ & $\mathbf{N}$ & $\mathrm{Y}$ & $Y$ & $\mathbf{N}$ & $\mathbf{N}$ \\
\hline Uruguay & $1969-75$ & & & & $?$ & $\mathbf{N}$ & $\mathbf{N}$ & $\mathbf{N}$ \\
\hline \multirow[t]{2}{*}{ Zambia } & $1966-70$ & & & & Y & $\mathbf{Y}$ & $\mathbf{N}$ & \\
\hline & $1987-90$ & $\mathbf{Y}$ & $\mathbf{N}$ & $\mathbf{N}$ & $\mathbf{Y}$ & $\mathbf{Y}$ & $\mathrm{Y}$ & $\mathrm{Y}$ \\
\hline Zimbabwe & $1978-83$ & $\mathbf{N}$ & $\mathbf{N}$ & ? & $\mathbf{Y}$ & $\mathbf{N}$ & $\mathbf{N}$ & \\
\hline
\end{tabular}

Note: $Y$ indicates that growth increases during the boom and is greater on average during and after the boom than before; ? indicates that growth increases during the boom and no data are available for the period after the boom. All other cases are denoted $\mathbf{N}$.

Source: Author's calculations based on information in the World Bank's World Saving Database.

terms of trade suggests that wealth (euphoria) effects most often account for the emergence of consumption booms.

Other factors may also be important. The probit results suggest that booms occurred during periods in which the real exchange rate was relatively appreciated. The results for individual booms suggest that booms often have been followed by real depreciation, consistent with the Dornbusch hypothesis.

Booms may also have been driven by an anticipated acceleration of economic growth or by financial sector expansion caused by domestic financial policies or capital inflows. The evidence is weaker for both of these mechanisms, because of 
the conflicting results in sections II and III and because of a strong likelihood of reverse causation. The increases in the growth rate of real output and in the share of credit to the private sector that were often associated with the emergence of individual booms are consistent with hypotheses emphasizing these phenomena as driving forces. But neither variable proved to have an independent effect in the probit regressions after other potential causal forces and potential endogeneity were taken into account. Although reverse causation is an obvious interpretation, it may not be a complete explanation; the acceleration in economic growth was not restricted to the boom period, but often followed it, and when lending booms were associated with consumption booms, consumption booms tended to be followed by financial crises, suggesting a potential causal role for financial market policies.

Factors relying on changes in intertemporal relative prices arising from interest rate movements appear to have a more restricted scope in triggering booms. The evolution of real and nominal interest rates did not often accord with such hypotheses, and where it did, the magnitudes involved were not generally large enough to suggest that intertemporal reallocation of consumption may have catalyzed the booms. Of course, these hypotheses were designed to apply only in the specific circumstances of exchange rate-based stabilizations. The upshot is that they are not likely to provide an understanding of the emergence of consumption booms outside of these specific circumstances.

A similar conclusion applies in the case of mechanisms relying on Ricardian effects on consumption. Relatively few of the consumption booms in the sample were followed by fiscal consolidation in the form of reduced public consumption. Again, this factor may have been important in specific cases. But booms do not seem to arise from the (correct) anticipation of reduced future tax liabilities due to fiscal consolidation.

Finally, disentangling the forces behind specific consumption booms usually will involve much more than determining whether or not the data are consistent with the specific macroeconomic mechanism underlying any single explanation. In many cases the data will prove to be consistent with more than one hypothesis. This is true of 15 of the 40 booms in tables 10 and 11. The scope for competing explanations may be narrowed by digging just a little deeper in some of these cases. But, more generally, understanding the factors underlying any single consumption boom, and thus understanding the policy implications of the boom, is likely to require quantifying the separate contributions made by more than one factor.

\section{REFERENCES}

The word "processed" describes informally reproduced works that may not be commonly available through library systems.

Calvo, Guillermo. 1989. "Incredible Reforms." In Guillermo Calvo, Ronald Findlay, Penti Kouri, and Jorge Braga de Macedo, eds., Debt, Stabilization, and Development. Oxford: Basil Blackwell. 
Caprio, Gerard, and Daniela Klingebiel. 1997. “Bank Insolvency: Bad Luck, Bad Policy, or Bad Banking?" In Michael Bruno and Boris Pleskovic, eds., Annual World Bank Conference on Development Economics 1996. Washington, D.C.: World Bank.

Deininger, Klaus, and Lyn Squire. 1996. "A New Data Set Measuring Income Inequality." The World Bank Economic Review 10(September):565-91.

Dornbusch, Rudiger. 1985. “External Debt, Budget Deficits, and Disequilibrium Exchange Rate." In Gordon W. Smith and John T. Cuddington, eds., International Debt and the Developing Countries, pp. 213-35. Washington, D.C.: World Bank.

Eichengreen, Barry, Andrew K. Rose, and Charles Wyplosz. 1995. "Exchange Market Mayhem: The Antecedents and Aftermath of Speculative Attacks." Economic Policy 21(October):249-312.

Montiel, Peter J. 1998. "Consumption Booms." Williams College, Department of Economics, Williamstown, Mass. Processed.

Rebelo, Sergio, and Carlos A. Vegh. 1996. "Real Effects of Exchange Rate-Based Stabilizations: An Analysis of Competing Theories." In Ben Bernanke and Julio Rotemberg, NBER Macroeconomics Annual, pp. 125-73. Cambridge, Mass.: National Bureau of Economic Research.

Reinhart, Carmen M., and Carlos A. Vegh. 1995. "Nominal Interest Rates, Consumption Booms, and Lack of Credibility: A Quantitative Examination." Joumal of Development Economics 46(April):357-78.

Rodríguez, C. A. 1982. “The Argentine Stabilization Plan of December 20th." World Development 10(September):801-11. 